\section{Technological Disruption: Millennials and the Practice and Teaching of Architecture}

Darius Sollohub

New Jersey Institute of Technology
The second decade of the twenty first century finds the practice and academies of architecture in the midst of an ongoing dis $\neg$ ruption. This paper discusses the economic upheaval that began this trajectory and its impacts on present and future architectural practice and teaching. How both the profession and academy can adapt depends on their understanding of the ascendant Millennial generation. An awareness of their demographic, technological, and learning characteristics can be essential in navigating the turbulence of technological transformation in the coming century.

\section{DISRUPTION}

The Great Recession, beginning in the late 2000s, began a disruption of the American architectural profession. The American Institute of Architects' Billing Index lost almost half its value from a high of 60.5 in 2005 to a low of 34.4 in $2009 .{ }^{1}$ The severity of the downturn forced architecture firms to cut almost a third of their staff and dramatically reorganized practice; causing firms to shrink, forcing many to merge, and cleansing the market of all but the smallest of nondigital firms. ${ }^{2}$

Demographers project yet more significant disruption due to technological change and other cultural shifts. In 2013, the Oxford University researchers Frey and Osborne examined over 700 U.S. occupations and their susceptibility to technological change. ${ }^{3}$ They project that 47 percent of total American employment is at high-risk and could expect to be automated within the next two decades. While they estimate automation will be principally confined to low-skill and low-wage occupations, they also find that "algorithms for big data are now rapidly entering domains reliant upon pattern recognition and can readily substitute for labor in a wide range of non-routine cognitive tasks. ${ }^{4}$ Without a specific timetable, Frey and Osborne set the probability of the computerization of architects at 1.8 percent and those of architectural drafters at 52 percent. This places architects in the low risk category with doctors and engineers (most under 2 percent), but places drafters in the more unnerving medium risk category alongside commercial pilots (55 percent). ${ }^{5}$ The specific destination for an architect's instructions are most susceptible: Frey and Osborne predict the almost complete automation of Brickmasons (82 percent), Roofers (90 percent), and Cabinetmakers (92 percent). Despite the variability based on category, and seeming immunity for higher-trained professionals, they stress that the effects will likely change the nature of work across entire industries and occupations. ${ }^{6}$ Eliminating the need for one out of two drafters, the traditional entry-level position for architects, will significantly disrupt the path toward licensure. And if there are any disciplines left in the construction phase, those tasks will be almost entirely be performed by machines.

Since Frey and Osborne's report, others have made similar forecasts: McKinsey Global Research generally supports their finding that roughly half the jobs are at high risk and go into greater detail about the pace and extent of change they expect will affect $\$ 16$ trillion in current wages in the global economy. While McKinsey predicts that less than 5 percent of human occupations will be erased entirely, the speculate that about two-thirds of all occupations will 
have at least one-third of its activities automated. They assert that more occupations will change fundamentally than will be automated away entirely. ${ }^{7}$

More recent (2015) and unsettling, Richard and Daniel Susskind in their Future of the Professions, assert that automation and innovation will effectively dismantle every profession and its teaching apparatus in the near future, specifically mentioning architecture alongside medicine, law, and even the clergy. ${ }^{8}$ The Susskinds claim that "we are on the brink of a period of fundamental and irreversible change in the way that the expertise of these specialists is made available in society." In their view, the current professions are antiquated, opaque and no longer affordable, with the expertise of the best enjoyed only by the few. The Susskinds conclude that as humanity inevitably transitions from a "print-based industrial society" to a "technology-based Internet society," the "grand bargain" struck between the laity and the professions will eventually be terminally rescinded. ${ }^{9}$

The Great Recession has had a parallel impact on professional architecture programs, with enrollments shrinking by 14 percent between 2008 and 2015. ${ }^{10}$ And while recovery began later in the decade, many schools were making up the deficit by admitting more non U.S. students, whose percentage in American architectural schools increased from 4 percent in 2009 to 24 percent by $2016 .{ }^{11}$

Poor employment prospects in the profession undoubtedly impacted schools. A 2012 Georgetown study reported unemployment among architecture graduates as twice that of those with engineering or business degrees. ${ }^{12}$ A follow-up 2015 report found unemployment among architecture graduates still high, even though the general economy had begun to improve. Most alarming, architects had the highest unemployment levels of those surveyed, even exceeding experienced workers with only a high school diploma. ${ }^{13}$ Through most of the recession, architects were buoyed by the U.S. Bureau of Labor Statistics projecting a 17 percent increase in demand for architects by 2022. ${ }^{14}$ But by 2016, it had scaled back its projection to no growth, suggesting that the decrease in architecture's labor force caused by the Great Recession could be more permanent than many had thought.

While gloomy job prospects undoubtedly hindered enrollment, other reasons contributed to decline. These included a recent memory of a relative who suffered in the recession, lower pay for architects compared to other professions, the lure of other creative fields related to the Internet, and architecture's reputation for long hours. Growing parental oversight might make any of these reasons enough to convince a teenager choose a different career path.

Despite these setbacks, the American architectural academy seemed to be expanding and ignoring the disruption entirely. At the beginning of the recession, 5 wholly new accredited architecture programs sought candidacy in 2009.15 Instead of maintaining a steady state, by 2015 , the number had grown to 18 programs either seeking or in candidacy. ${ }^{16}$ This expansion continued as almost half the graduates of accredited architecture programs in the United States did not seek licensure even though most had completed their internships. ${ }^{17}$
The travails of architectural academia must be seen against the background of broader disruption to higher education. Since the recession began digital learning has proliferated and renders the need to be in the classroom increasingly optional. Undergraduate students taking online courses rose from 15 percent in 2008 to 47 percent in 2014, ${ }^{18}$ and the sudden proliferation of Massive Open Online Courses (MOOCs) in 2008, and their early adoption by elite universities augers yet more dramatic change. ${ }^{19}$ Universities not able to join this transformation by producing their own online curricula may suffer. Kevin Carey in his book, The End of College, predicts that perhaps only 50 American colleges and universities will survive the disruptions of the twenty-first century, with digital technology causing schools to be absorbed or simply cease to exist. ${ }^{20}$

A looming demographic may trigger Carey's prediction. In his book Demographics and the Demand for Higher Education, Nathan Grawe projects a bleak enrollment outlook for most institutions as a byproduct of the recession. Because many delayed starting families as the economy collapsed, the college population will decline by approximately 15 percent starting around 2026, with the effect varying by region. ${ }^{21}$ Schools not well regarded by the remaining population may not recover.

\section{THE MILLENNIAL GENERATION}

The dramatic and dynamic change in both the architectural profession and academy occurred as the Millennial generation ascended. From various studies, one can generate a broad profile that finds Millennials to be self-confident, team-oriented, and outward-focused, with a pervasive digital acumen affecting each aspect of this characterization. While there is some dispute as to the bracketing years of the generation most agree that the first entered college around 2000. And while some skeptics contest their supposed positive characteristics, they agree they are distinct, populous in number, and understand how different they are from their forebears. Given that the values of the Millennial generation are likely to predominate in the coming decades (making the closing bracket of the generation moot), understanding how architecture relates to their profile can serve as a guide for how to weather the coming disruption.

As they came of age in the early twenty-first century, Millennials found many of their values aligning with architecture. The generation's youthful team-centered experiences found affiliation with increasing collaboration and interdisciplinarity, ${ }^{22}$ their practical nature embraced a pendulum swing in architecture from the theoretical to the pragmatic, ${ }^{23}$ and their civic focus found both a profes-sion and academy yearning to increase agency in the public realm. ${ }^{24}$ In the academy, the Millennials' predisposition to collaborative and goaloriented learning environments makes them favor studio-based education. That these generational alignments, preceded those of other disciplines, spared architecture some of the disruptive shock that rocked other sectors; its proto-Millennial qualities positioning architecture to benefit rather than suffer waves of disruptive change, a dynamic that is likely to continue through the first half of the twenty-first century. 


\section{BUILDING INFORMATION MODELLING}

A primary natural alignment has to do with computing. Building Information Modelling (BIM) reverberates with Millennial values in its focus on an optimized practicality, and emphasis on a necessary collaboration to replace obsolete methods. ${ }^{25}$ The platform also resonates with their preference for flexibility and control. In advocating for BIM, Phillip Bernstein envisions integrated teams working within a trusting and transparent environment based on a revolving agency of merit-based control, operating according to "collaborative models that combine responsibilities, risks, and rewards, and that provide open access to information, [in which] disputes over control give way to the issues of leadership: who is best suited to make a decision that benefits the project itself?"26 A related attitude of collaboration will enhance Integrated Project Delivery (IPD), the new business model that BIM has spawned by taking advantage of billions of devices communicating with one another and with the Internet of Things. This enhanced connectivity will accompany a project from conception to construction and into its future. Like the tag given by some to the Millennial generation for their unprecedented connectivity, these projects-from the moment of inception to well after demolition-will be "always on."

A Millennial embrace of BIM can fortify the profession as automation takes hold. Autodesk's Project Dreamcatcher, the software manufacturer's next generation of computational design, can already formulate thousands of design options to satisfy specified objectives, including functional requirements, material type, manufacturability, performance criteria, cost restrictions, etc. ${ }^{27}$ Dreamcatcher and programs like it will redefine design as selecting from multiple options, albeit options created by the architect's prompts. Dreamcatcher may be either a first step of a digital encroachment on the architect's domain, or the path for the Millennial architect to assert themselves in the future.

\section{ONLINE LEARNING; SOCIAL NETWORKS; AND GAMING}

How architecture responds to the Millennials' penchant for anytime/ anywhere nomadicity, social networks, and digital games remains controversial. For some, these practices represent the ultimate distraction, for others (following a lead begun outside the discipline of architecture) they constitute an opportunity. Some adaptive strategists are eager to build upon an anytime/anywhere nomadism, while the countervailing naysayers add nomadicity's effects to the growing list of Millennial liabilities that skeptics identify, forecasting the progressive undermining of architecture's physical and organizational structures. If one sides with the adaptive strategists, adding online learning, social media and digital games to a combined professional and academic toolbox expresses faith, and not concern, over Millennials.

Online learning rests at the core of Millennial nomadism, appealing to their desire for education that is flexible and convenient. Although enrollment in online courses continues to grow, if given the option, Millennials express in polls how they would choose another form of course delivery. ${ }^{28}$ In response, many institutions have adapted.
One variant is to offer a practice known as "convergence," or providing the same material online as in the classroom. Another is to offer hybrid learning courses. Often referred to as the "flipped classroom," 29 these deliver course lectures online, reserving class time for the exercises and projects a student formerly did as homework. Given that students have had time to digest material, discussions held in the classroom are more interactive. Advanced forms of hybrid learning include assessment in the form of quizzes at the end of each online tutorials, revealing to the instructor whether online materials have been viewed, and based on overall performance, which subject matter needs to be focused on in class. An even more advanced form, "adaptive learning," analyzes student results to determine deficiencies and custom-tailors future study until a learner achieves an adequate level of competency. ${ }^{30}$ Online learning increasingly uses "badges," which are akin to the merit badges of youth scouting programs. These describe a learner's specific achievements through the use of detailed metadata that reveals relevant information: what organization issues the badge; what has to be accomplished to earn it; scores on tests, or the tests themselves; it can also include a portfolio of class work. ${ }^{31}$ Online learning and badges can have many applications in architectural education. A hybrid and adaptive transformation of the ancillary courses of architectural education-technology, history, and practice-can enhance studio teaching with badges providing evidence that a student is technically proficient to take a certain studio. Badges can become integral to accreditation, and after graduation, part of the exam process and continuing education. And in a manner to how LEED accredits professionals, badges can provide a way to distinguish oneself in a crowded marketplace.

Social networks represent yet another form of nomadism disrupting education. In the mainstream, these have expanded connectivity to establish entirely new forms of community. Education writer Roger McHaney describes how social networks influence education as a form of "connectivism," arguing for their necessity in absorbing the vast amount of information the Internet has made available. ${ }^{32}$ By forming Personal Learning Networks (PLNs), McHaney advocates for the creation of persistent and relevant network of community learning to reach interested people and information outside the classroom. Within architectural education, social networks remain an unexploited resource and can provide a virtual extension of the classroom and studio, organizing information according to topic, project, need, etc..

A penchant for digital games is a hallmark of tech-savvy Millennials. For the youngest, playing a video game may have been a first memory. Communication and education scholar Deborah Lieberman describes the multiple learning benefits of digital games, many of which align with Millennial characteristics. Like their analog precedents, digital games are by definition experiential, providing activity that encourages 
learning by doing. Computer games are participatory and engaging, with customized, rapid feedback that wards off distraction and makes one pay close attention. A game's consequences are not abstract or hypothetical but represented in the game directly. When played with others, games are collaborative, becoming a social medium. By giving positive feedback in awarding points, power, or rank for thoughtful planning and decision-making, games can build confidence; one gains self-assurance in order to succeed (and survive). Lieberman goes so far as to argue that even when players interact with virtual personae, a player's ego and self-image are so invested in the experience, game characters who can serve as role models for players, their simulated interactions and emotional responses providing a form of social training. ${ }^{34}$ Digital games have become increasingly sophisticated in their use of virtual space, forming a sub-genre known as "city-building games," also known as "construction and management simulations" (CMS). In CMS, a player's goal is to build within the context of an ongoing process amidst periodic crises, such as fires or earthquakes. ${ }^{35}$

Given CMS games spatial component, it seems rather surprising how so little has migrated to architectural education. This indicates how inattentive architecture has been to Millennial tendencies, despite the early advantage in digital technology that architecture once held. The reasons for this are perplexing and there may be many causes. Nonetheless, the end result is that other professional programs have far outpaced architecture: as of 2018, online engineering programs numbered 2,072, and business 5,215. By comparison architecture counted only 36 , with only 4 offering professional degrees. ${ }^{36}$ The architectural academy's related nonacceptance of social media and gamification may be from a desire to insulate the all-ornothing charrette environment from the addicting procrastination social media and games have caused in the general population. ${ }^{37}$

A course correction toward a Millennial nomadism can have many benefits: a hybrid supported studio, with some even taught through games, enhanced by a connectivism linked directly to knowledge learned as well as the billions of assets of the internet, can be a powerful educational model to encounter future disruption. Otherwise, unencumbered by any prior prejudice, and having only experienced the practical benefits of online learning, social media, or digital gaming, Millennials will follow a path of greatest convenience to expand their use. They may even go elsewhere to be trained how to build.

\section{ONGOING AND POTENTIAL ADAPTATION}

In many respects, the architectural community has begun adapting to the Millennial wave in acknowledging their generalized characteristics. In 2013, the AIA issued a forward-looking document that included the following description:

"The youngest generation of workers, children of both Baby Boomer and Gen X parents, have different work styles, preferences and expectations than their predecessors. Millennials are characterized as natural collaborators who integrate communication and work technologies deeply and seamlessly. They value quality of experience and learning opportunities over extrinsic rewards, and crave regular feedback and encouragement... Many firms realize that their mid- to senior-level managers have difficulty leading the adoption of new technologies and look to their Millennial workers to drive adoption of advanced tools." 38

The AIA has continued efforts to support Millennial characteristics in other ways, including a public awareness campaign through various media that includes a film competition, ${ }^{39}$ financially support-ing design centers and a social impact mission that Millennials are drawn to, and promoting technologically driven ways to advance the collaboration driven platforms of Building Information Modeling (BIM) and Integrated Project Delivery (IPD). The National Council of Architectural Registration Boards (NCARB) has overhauled many aspects of licensure, rewriting the licensing exam to better reflect new modes of practice that include instant results, encouraging experimentation by schools to decrease the length of internship, ${ }^{40}$ and improving its social media presence to demystify the internship and licensure process. So, if the profession and academy are already naturally absorbing Millennials, why should any further accommodations be made? While adopting a laissez-faire attitude may ultimately effectively blend Millennials with the architectural community, doing so still ignores the gravity of the current disruption and the shock of automation yet to come. It also ignores the opportunity to turn the disruption into an advantage.

Advances in software will undoubtedly affect the labor structure of architectural offices, perhaps reaching Frey and Osborne's prediction that the role of the drafter will be significantly computerized. How architecture anticipates advances such as Dreamcatcher and integrates this automation will be critical to its future. Recognizing that while the profession might see automation as an incursion on its jurisdiction, society at large, as the Susskinds contend, may instead see democratization with a significant cost-savings. Clients will expect to draw on some of automation's cost savings related to design fees, as will the software provider through licensing. The remainder will go to the software's operator who achieves expectations. This leaves no guarantee of what the architect's share will be, if any. The sooner the architecture begins to experiment with some form of automation, organizing Millennials and their innate technological skill at the controls, the better chance it will have of claiming its fair share of this savings.

In the academy, educators will have to recalibrate pedagogy to respond effectively to both computerization and other threats to the profession. Architecture's early and steady embrace of computers beginning in the 1980s has provided a platform for a digitally native Millennial mindset to accelerate from, but students will need to transcend software competence and be able to master its code. Mastery will allow them to take command of future artificial intelligence organized around BIM, effectively utilizing its built-in collaborative possibilities to advance IPD and break disciplinary silos. Architects will also need to expand their purview to embrace the practical importance of economics, finance, and management, as well as complement graphic skills by better teaching verbal and written communication. ${ }^{41}$ And if architecture can overcome its overemphasis on working individually 
and competitively, it can leverage a Millennial propensity to work collectively, thereby sharing a common professional knowledge base that can expand its jurisdiction to other disciplines.

The dire forecast of a technological disruption to the architectural academy and profession parallels what threatens other sectors of society. Understanding the Millennial generation can serve as a critical guide to benefit from the advantages the generation brings, while also positioning architecture to adapt to the Millennial's unique characteristics. Doing both can help architecture in not only dealing with current upheavals, but to also potentially advance its agency as the future of its academy and profession unfold.

\section{Notes}

Select ideas in the above are excerpted from the authors book: Millennials in Architecture: Generations, Disruption and the Legacy of the Profession. (Austin: University of Texas Press, 2019)

1. Architect: The AIA Magazine (Jan 2014) pp.110-11 The Architectural Billings Index (ABI) is computed as a diffusion index, with the monthly score calculated as the percent of firms reporting a significant increase plus half the percent of firms reporting no change. Comparisons are always to the previous month.

2. 2012 AIA firm survey as reported in Architect: The AIA Magazine (Jan 2013) p. 112. By late 2014, the recovery seemed to have begun with the AIA Billing Index rising to 54.6 by September. See Baker, Kermit "Architecture Firms Remain in Growth Mode," Practicing Architect (AIA: Nov 2014) Retrieved 5/8/15 from http://www.aia.org/ practicing/AIAB104905

3. Frey, Carl B. and Michael A. Osborne. "The Future of Employment: How Susceptible are Jobs to Computerisation?" Oxford Martin Programme on Technology and Employment Working Paper (Sep 17, 2013) Retrieved 5/16/16 from: www. oxfordmartin.ox.ac.uk/downloads/academic/The_Future_ of_Employment.pdf

4. IBID p. 44.

5. IBID. pp. 57-72. Architects occupations and drafters rank 305th out of 702. Frey and Osborne exclude landscape and naval from architects and include civil drafters with architectural. For additional comparison, lawyers are at medium risk ranking 115th out of 702 at 35 percent.

6. IBID pp. 44-5

7. McKinsey Global Research. "A Future That Works: Automation, Employment, and Productivity." (Jan 2017)

8. Susskind, Richard and Daniel. The Future of the Professions. (Oxford: Oxford University Press, 2015).

9. IBID p. 27. The Susskinds use Donald Schon's description to describe the grand bargain: "In return for access to their extraordinary knowledge in matters of great human importance, society has granted [the professions] a mandate for social control in their fields of specialization, a high degree of autonomy in their practice, and a license to determine who shall assume the mantle of professional authority."

10. ACSA. "Architecture Schools Face Budget \& Enrollment Changes," (Mar 22, 2013) Retrieved 4/2/14 from http:// www.acsa-arch.org/acsa-news/read/read-more/acsanews/2013/03/22/architecture-schools-face-budgetenrollment-changes\#.dpuf

11. A comparison of the National Architectural Accrediting Board 2009 Report on Accreditation in Architecture Education (February 2010) with data from 2016 finds the nonresident alien population increasing from $6 \%$ of enrollment overall in 2009 to $24 \%$ when counted in 2015-16. See Association of Collegiate Schools of Architecture. "Trends in International Student Enrollment in Architectural Education." (December 2016) Retrieved 2/24/17 from www.acsa-arch.org/resources/ data-resources/international-students-in-architecturaleducation/. While there may be nothing inherently wrong with what is effectively an export of education, this strategy leaves schools vulnerable if more restrictive federal immigration policies deter international students from applying. An 18 percent drop nationwide after the 9/11 attacks is a reminder of just how volatile foreign enrollments can be. See Fischer, Karin. "Colleges Are Wary of Global Economy's Effect on Foreign Enrollments," The Chronicle of Higher Education (Jul 16, 2012) Retrieved 2/11/13 from: http://chronicle.com/ article/Colleges-Are-Wary-of-Global/132875/

12. Georgetown University Center on Education and the Workforce. p. 7

13. The Georgetown University Center on Education and the Workforce. Anthony P. Carnevale, Ban Cheah. "From Hard Times to Better Times: College Majors, Unemployment, And Earnings." (Feb 19, 2015) p. 8 Retrieved 6/3/15 from https://cew.georgetown.edu/wp-content/uploads/ HardTimes2015-Report.pdf

14. This represents an increase over average economic growth. Bureau of Labor Statistics, U.S. Department of Labor, Occupational Outlook Handbook, 2014-15 Edition, Architects. Retrieved 5/30/15 from http://www.bls.gov/ooh/ architecture-and-engineering/architects.htm

15. The National Architectural Accrediting Board. 2009 Report on Accreditation in Architecture Education (February 2010)

16. The National Architectural Accrediting Board. 2015 Annual Report Part III: 2015 Accreditation Decisions and other NAAB Activities. (2015)

17. According to the 2015 NCARB By the Numbers, this number was 2,700 of 6,000 on average since 2008.

18. Dahlstrom, Eden, and Jacqueline Bichsel. "ECAR Study of Undergraduate Students and Information Technology, 2014." Research Report. Louisville CO: ECAR (October 2014) Retrieved 5/7/15 from: https://net.educause.edu/ir/library/ pdf/ss14/ERS1406.pdf. p.22. Although many report doing 
so more as a matter of convenience or necessity and not necessarily preference

19. Hollands, Fiona M. and Devayani Tirthali. "MOOCs: Expectations and Reality." Center for Benefit-Cost Studies of Education, Teachers College, Columbia University (May 2014) Retrieved 5/7/15 from: http://cbcse.org/wordpress/ wp-content/uploads/2014/05/MOOCs_Expectations_ and_Reality.pdf

20. Carey, Kevin. The End of College: Creating the Future of Learning and the University of Everywhere (New York: Riverhead 2015) pp. 72-3. Schools most at risk include public universities hampered by decreases in state support, private universities without strong endowments, and for-profit universities operating on thin financial margins.

21. Nathan Grawe, Demographics and the Demand for Higher Education. (Baltimore: Johns Hopkins 2018)

22. Allen, Stan. "The Future That Is Now" in Joan Ockman, ed.. Architecture School: Three Centuries of Educating Architects in North America (Cambridge MA: MIT Press 2012) p. 216, 224. See also Waldheim, Charles, ed. The Landscape Urbanism Reader. (Princeton NJ: Princeton Architectural Press 2006)

23. Allen, Stan, et.al.. Stocktaking 2004: Questions about the Past, Present and Future of Design. in Saunders, William S., ed.. The New Architectural Pragmatism, A Harvard. Design Magazine Reader. (Minneapolis, University of Minnesota Press, 200 7)p. 103

24. Cary, John M. Jr.. The Power of Pro Bono: 40 Stories About Design for the Public Good by Architects and Their Clients (New York: Metropolis, 2010)

25. see Ashcraft, Howard W. "Furthering Collaboration," in Deamer, Peggy and Phillip G. Bernstein, eds. Building (in) the Future. (New York: Princeton Architectural Press, 2010) pp. 145-158

26. Bernstein, Phillip. "Models for Practice: Past Present and Future," in Deamer, Peggy and Phillip G. Bernstein, eds. Building the Future. (New York: Princeton Architectural Press, 2010) p. 197

27. Retrieved 9/26/16 from: autodeskresearch.com/ projects/dreamcatcher

28. Craig, Ryan. "A Brief History (And Future) Of Online Degrees" Forbes Magazine (Jun 23, 2015) Retrieved 9/22/16 from: www.forbes.com/sites/ryancraig/2015/06/23/a-briefhistory-and-future-of-online-degrees/\#473873097e37

29. "7 Things You Should Know About Flipped Classrooms" (Educause: 2012) Retrieved 8/28/16 at net.educause.edu/ir/ library/pdf/eli7081.pdfEducause

30. IBID

31. Carey, Kevin. The End of College: Creating the Future of Learning and the University of Everywhere. (New York: Riverhead Books, 2015) pp. 203-219 see also "7 Things You Should Know About Badges" (Educause: 2012) Retrieved 8/28/16 from: net.educause.edu/ir/library/pdf/eli7085.pdf
32. $\mid \mathrm{BID}$

33. Schnabel, Marc Aurel and Jeremy J. Ham. "A Framework for Social Networked Architectural Education" in Stouffs, Rudi et al eds.. "CAADRIA 2013: Open System : Proceedings of the 18th International Conference of the Association of Computer-Aided Architectural Design Research in Asia," (2013) pp. 313-322

34. Lieberman, D. A.. "What Can We Learn From Playing Interactive Games?" In P. Vorderer \& J. Bryant eds., Playing Video Games: Motives, Responses, and Consequences. (Mahwah, NJ: Lawrence Erlbaum Associates, 2006)

35. Rollings, Andrew; Ernest Adams. Andrew Rollings and Ernest Adams on Game Design. (San Francisco: New Riders Publishing, 2003) pp. 417-20.

36. www.guidetoonlineschools.com. SR Education Group. Retrieved 6/4/18 from: www.guidetoonlineschools.com/ degrees. That Art and Design programs number 281 and Architecture only 36 fails to support the often-heard excuse among architecture academics that the artistic content of architecture defies online education.

37. Song, Indeok et al. "Internet Gratifications and Internet Addiction: On the Uses and Abuses of New Media."CyberPsychology \& Behavior. (Sep 2004) vol. 7 no. 4. Pp. 384-394

38. The AIA Foresight Report: The Changing Context, Business, and Practice of Architecture 2013

39. The AIA's Public Awareness advertisement campaign, developed with The Purpose Institute of Austin, Tx is a comprehensive three-year plan to emphasize the value that architects bring to shaping the built environment. The Look Up Film Challenge unites storytellers and the architectural community to describe architects' impact on our built world in YouTube styled videos.

40. Massie, Caroline. "13 Architecture Schools to Bring Path to Licensure Into Curricula." Architecture Magazine (August 31, 2015) Retrieved 7/8/16 from: www.architectmagazine. com/practice/13-architecture-schools-to-bring-path-tolicensure-into-curricula_o As of 2015 the National Council of Architectural Registration Boards (NCARB) has begun working with 13 accredited architectural programs as part of its Integrated Path Initiative, which allows students (undergraduate and graduate) to begin the licensure process as a part of an academic curriculum and take each division of the Architect Registration Examination (ARE) before graduation. NCARB is guiding each school in the process and also coordinating with local state regulators to ensure compliance. Each school will implement the restructured program according to the unique schedule established with its administration and faculty.

41. Fisher, Thomas. In the Scheme of Things: Alternative Thinking on the Practice of Architecture. (Minneapolis MN: University of Minnesota Press, 2000) pp. 27-37 